\title{
The State of Preparedness for Digital Curation and Preservation: A Case Study of a Developing Country Academic Library
}

Phillip Ndhlovu ${ }^{1}$ and Thomas Matingwina ${ }^{2}$

\begin{abstract}
Digital technologies have allowed libraries to create, manipulate, store and make accessible vast amounts of digital content. However, they endanger the longevity of the very objects they produce and require very different management than the traditional paper-based world. Despite the fact that the National University of Science and Technology (NUST) Library in Zimbabwe has amassed a huge body of digital collections, there are no formal mechanisms to ensure accessibility and long-term preservation of digital content. The study assessed the state of preparedness of NUST Library for digital curation and preservation of its digital collections. The conceptual framework was based on Sinclair et al. (2011) and Boyle, Eveleigh, and Needham's (2008) formulations. NUST Library preparedness for digital curation and preservation was assessed by examining awareness, competencies, technology infrastructure, digital disaster preparedness and challenges to digital curation and preservation. A mixed methods research design employing a case study research strategy was adopted for the study. The findings revealed a low level of awareness of digital curation and preservation. Challenges to digital curation are mainly lack of policies, lack of expertise by library staff and lack of funding. It is recommended that the Library should consider digital curation and preservation as one of the primary responsibilities and take staff members' training in this area seriously in order to ensure current and future access to digital collections.
\end{abstract}

\section{Keywords}

Digital curation, digital preservation, digital disaster preparedness, data management

\section{Introduction and Background}

As digital data and technologies have fast become an integral aspect of 21st century life, public organisations, particularly libraries, are facing increasing demands for digital services from users who "routinely and unthinkingly" use or depend upon digital information (Pennock, 2007). Many libraries have responded to digital technologies by setting up digital libraries and digital repositories, especially academic and research libraries (Kim, Warga and Moen, 2012). This has opened up an opportunity for libraries to manage and make available different types of digital content. However, Lee and Tibbo (2007) are of the view that digital technologies pose a threat to the permanence of the very objects they produce and require very different management than what has been practiced in the paperbased world. Addressing the preservation and long-term access issues for digital resources are some of the key challenges facing libraries and information centres today (Alemneh, Hastings and Hartman, 2002). The challenges are enormous in developing countries due to lack of adequate resources and technologies for effective digital resources management and preservation (Boamah, 2014).

Currently, libraries may manage digital content in three primary ways; providing access to metadata and electronic full-text for publisher or vendor content, managing digitized local collections, and managing institutional, scholarly digital assets (Miller and Blake, 2011). The researchers work at the National University of Science and Technology (NUST) Library in Zimbabwe and have observed that the library has embraced the practice of e-collection and digitization by establishing a number of 
digital collections in order to meet the demands of the $21^{\text {st }}$ century clientele. As a result, the library has amassed a large body of valuable digital assets and information which include among other things institutional records, faculty and student research, theses and dissertations, university publications, past exam papers, multimedia collections and course materials.

The digital collections which have been established over the years include; (1) the Online Public Access Catalogue (OPAC) Database, (2) the Nustone Digital Library, (3) Research Guides Database, (4) the NUST Institutional Repository (NuSpace) as well as a collection of physical storage media such as CDROM, CDs, DVDs and floppy disks. These digital collections are complemented by providing access to e-books, e-journals, the library website as well as social networking platforms. The mission of one of its digital collections is to collect, preserve and disseminate the intellectual output of NUST community and make academic work freely available to researchers and the general public (NuSpace, 2016). However, there are no formal mechanisms and sustained strategies in place to ensure accessibility and long-term preservation of digital content at NUST Library.

\section{Literature Review}

There is a growing realisation that current and future access to digital resources is threatened by technology obsolescence, fragility of digital media as well digital disasters (McGovern, 2009). Given the dynamic nature of information technologies and the obsolescence issues associated with them, it is important to put in place digital preservation strategies to ensure that digital resources are preserved and remain accessible and useable over time (International Records Management Trust, 2004). Several studies have highlighted that it is impossible for digital information to survive or remain accessible by accident and that pro-active preservation strategies are vital. Digital resources require well planned, well managed, and sustained strategies over their entire existence (Yale University Library, 2011). Unlike print resources, benign neglect is not an option for digital information because of eventualities such as physical media decay, corruption of digital files and hardware and software obsolescence (Miller and Blake, 2011). The South African National Research Foundation (NRF) (2010) notes that sound digital curation and preservation requires inter alia; expertise, human and financial resources, technology infrastructure, adoption of standards, creation of guidelines and implementation of policies. However, most African Libraries and Information Centres are poorly equipped for digital curation and preservation (Kanyengo, 2006).

A number of studies have highlighted problems that arise when libraries lack policy strategies for digital curation and preservation. These studies also give pointers to elements that should be looked at when assessing preparedness for digital curation and preservation. Sinclair et al. (2011) reported on the findings of a Planets survey which was done in 2009 of two hundred organisations, mainly European archives and libraries, to investigate their preparedness for digital curation and preservation. Preparedness was assessed looking at awareness of digital preservation, digital preservation policies, and digital preservation's inclusion in organisations' general planning, budgets for digital preservation and timescales for investment (Sinclair et al. 2011). Results indicated that organisations without a digital preservation policy were four times more likely to have no experience or be unaware of the challenges presented by digital preservation, three times more likely to have no plans for the long-term management of digital information, and more than twice as likely to put off investing in digital preservation technological solutions.

A survey of the preparedness for digital preservation of Local Authority Archives in the United Kingdom was conducted by Boyle, Eveleigh, and Needham (2008) where over 80 percent of the respondents already held digital collections. Preparedness for digital preservation was assessed in terms of digital preservation planning, general awareness of digital preservation, current practical digital preservation strategies, infrastructure and staffing requirements. The results indicated that awareness of essential issues of digital curation and preservation was particularly low in those organisations without a preservation policy. In the same study, barriers to digital curation and 
preservation were identified as cultural (organisation, political, awareness, external partnerships/relations and motivation), resources (time, costs, funding and storage), and skills gap (training, competencies and information technology).

Other studies examined digital disaster preparedness as an essential component of preparedness for digital curation and preservation (Zaveri, 2015; Frank and Yakel, 2013; Jiazhen and Daoling, 2007). Frank and Yakel (2013) note that our understanding of disaster planning for digital collections remains limited, both in terms of what constitutes disaster planning activities as well as whether any best practices have emerged in planning for different types of risk.

A number of studies have showed that competencies or skills are vital for libraries and information centres to be fully prepared for digital curation and preservation (Atkins et al, 2013; Groenewald and Breytenbach, 2011; Hockx-Yu, 2006). However, most studies have concentrated on skills that are required for digital curation and preservation and have been carried out mainly in developed countries (Raju, 2014). There are gaps in the literature for studies that assess possession of these skills by librarians working in a digital environment. Uluocha (2014) argues that in many African countries, human resources with appropriate skills, competences and attitudes are not readily available to initiate, implement and sustain preservation projects. Researchers have noticed gaps in academic libraries, particularly a need for appropriately trained information professionals to act on opportunities for supporting digital curation activities (Soehner, Steeves and Ward, 2010).

Matsika (2014): , as cited in the NUST Vice Chancellors Annual Report (2014:55): , notes that more students now have access to lap tops, I-pads and smart phones and prefer the library's electronic information over print resources. Hedstrom (2001) highlighting the importance of digital curation and preservation notes that once users become accustomed to accessing information online they do not want those resources to be removed or diminished. However, for libraries to ensure access to digital information to current and future users, there is need to assess their preparedness for digital curation and preservation in order to acquire the necessary information to allocate resources for their stewardship. 


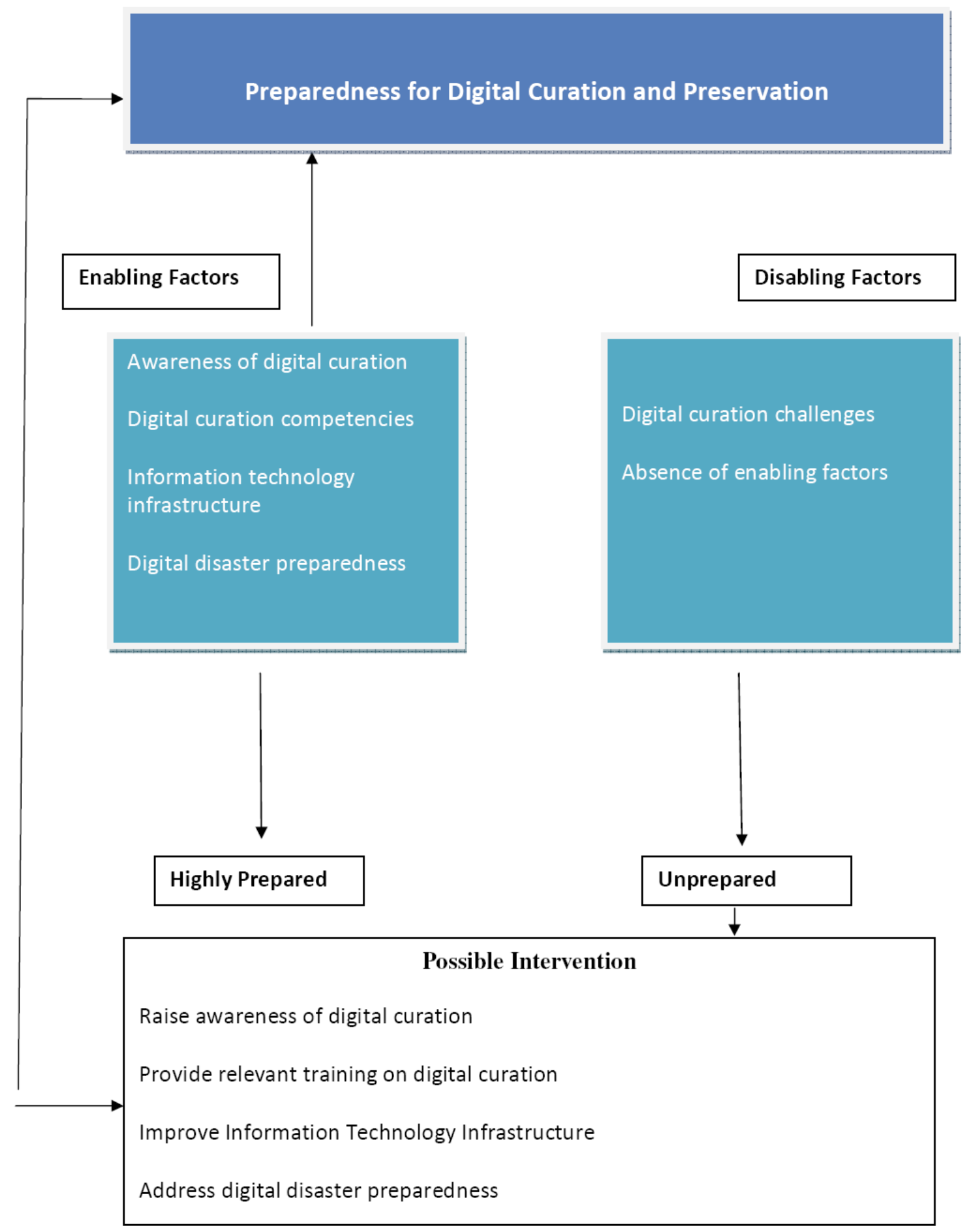

Figure 1: Conceptual Framework (Researcher, 2018) Key: Dependent Variable Independent Variables Unidirectional Relationship Dual Directional Relationship

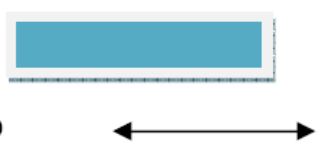

\subsection{Purpose of the Study}

This study aimed to assess the state of preparedness of NUST Library for digital curation and preservation of its digital collections using the conceptual framework highlighted in Figure 1. 
The study's conceptual framework was inspired by the criteria used by Sinclair et al. (2011) in a survey of two hundred organisations, in mainly European archives and libraries, to investigate their preparedness for digital curation and preservation. It was also inspired by the criteria for preparedness used by Boyle, Eveleigh, and Needham (2008) in a survey of the preparedness for digital preservation of Local Authority Archives in the United Kingdom. However, the researchers added some variables which they deemed necessary for assessing preparedness for digital curation and preservation based on the literature review.

\subsection{Research Objectives}

The study addressed the following important research questions:

i. What is the level of librarians' awareness of digital curation and preservation?

ii. To what extent are library staff competencies able to meet digital curation and preservation needs?

iii. To what extent is the available information technology infrastructure able to support digital curation and preservation requirements?

iv. What is the level of digital disaster preparedness at NUST Library?

v. What challenges are faced by the Library in digital curation and preservation?

\section{Methodology}

A mixed method research design was chosen for the study. Johnson and Onwuegbuzie (2004:18) define mixed methods research as the mixing or combination of quantitative and qualitative research techniques, methods, approaches, concepts or language into a single study. The following reasons cited by Denscombe (2008) justify the adoption of a mixed research approach:

1) to improve the accuracy of research data

2) to produce a more complete picture by combining information from complementary kinds of data or sources

3) to avoid biases intrinsic to single-method approaches - as a way of compensating specific strengths and weaknesses associated with particular methods.

The case study approach was adopted as the research strategy for the study. Yin (1984:23) defines the case study research method as "an empirical inquiry that investigates a contemporary phenomenon within its real-life context; when the boundaries between phenomenon and context are not clearly evident; and in which multiple sources of evidence are used". Mixed methods research design complements the case study research strategy as it allows the researcher to combine multiple sources of evidence and apply either quantitative and qualitative methods to the data (Kitchenham, 2010).

The library had a total population of 52 Library staff members and purposive sampling was used to recruit 32 participants for the study. The rationale for this approach was that the researcher was able to select respondents who work with digital collections or were in library management and were in a position to provide relevant data. The following participants were included in the study based on the researcher's knowledge and research experience (Welman, Kruger, and Mitchell, 2005: 69):

1) Deputy Librarian 
2) Library Systems Librarian/IT Manager

3) Library IT Technician

4) Assistant Librarians and

5) Chief/Senior Library Assistants

Questionnaires, observation schedules, interview guides and focus group discussion guide were used as research instruments. The researcher started by individually notifying all respondents of the intention to do research at the NUST library through email. Details of the study were conveyed along with issues of confidentiality and or anonymity. The researcher made appointments and visited the offices of only two interview participants, the Deputy Librarian and the Library Information Technology (IT) manager to discuss appropriate date, venue and time for the interviews. The interviews were held in their offices at their convenience. The researcher decided to use the services of the student interns to distribute and collect questionnaires from the participants. This ensured strict anonymity of respondents. The researcher consulted the participants about the appropriate time and venue for the focus group discussion. A voice recorder was used with the permission of the participants. Observation was done focusing on the items listed in the observation schedule. A digital camera was used to take visual images of some of the observations with the permission of the Librarian and the University Registrar.

To ascertain the validity of the questionnaire, a pilot study was done with 5 respondents from among the Library staff. Content validity for the study was ensured by identifying all the major independent variables necessary in the existing literature. The pilot study revealed that the participants did not understand the phrase 'digital curation'. The final questionnaire included a brief explanation in order to make it easier for participants to respond. Other minor adjustments were made to the questionnaire based on the results of the pilot study. Results of the study were shared with the participants and permission was sought to have their work role titles published in this research article.

The study employed both qualitative and quantitative data analysis. Descriptive analysis was used to report the study findings. The use of frequency distribution, percentages and averages was implemented to describe the results. Miles and Huberman's (1994) qualitative data analysis techniques were used. These are;

1) Organization/categorization of the data into concepts ;

2) Connection of the data to show how one concept may influence another;

3) Corroboration/legitimization by evaluating alternative explanations, disconfirming evidence, and searching for negative cases and

4) Representing the account (reporting the findings).

\subsection{Limitations of the study}

The study was limited by its nature since ascertaining the preparedness may involve attitudinal investigation and attributes which may be regarded as sensitive and might hinder participants from responding objectively. Another limitation was that the researcher is an employee of the NUST library. There was, therefore, a possibility of bias on the part of the respondents. However, to mitigate this effect, the researcher carried out interviews and observation to support the stated facts.

The field of digital curation is still emerging with many different contributions from a great number of scientists that make it even more difficult to define concepts and theories (Palavitsinis, Manouselis 
and Sanchez-Alonso, 2010). However, the researcher narrowed the scope of digital curation and preservation activities by using the conceptual framework identified in literature.

\section{Results}

\subsection{Description of Participants}

Thirty library staff took part in this study. Questionnaires were distributed to 31 members of staff and 29 were returned representing a $94 \%$ response rate. However, interviews were conducted with the Deputy and Library IT manager. Figure 4.2 shows the number of staff members who participated in the study. The majority were Chief/Senior Library Assistants who numbered 19 , representing $63 \%$ of library staff who took part in the study.

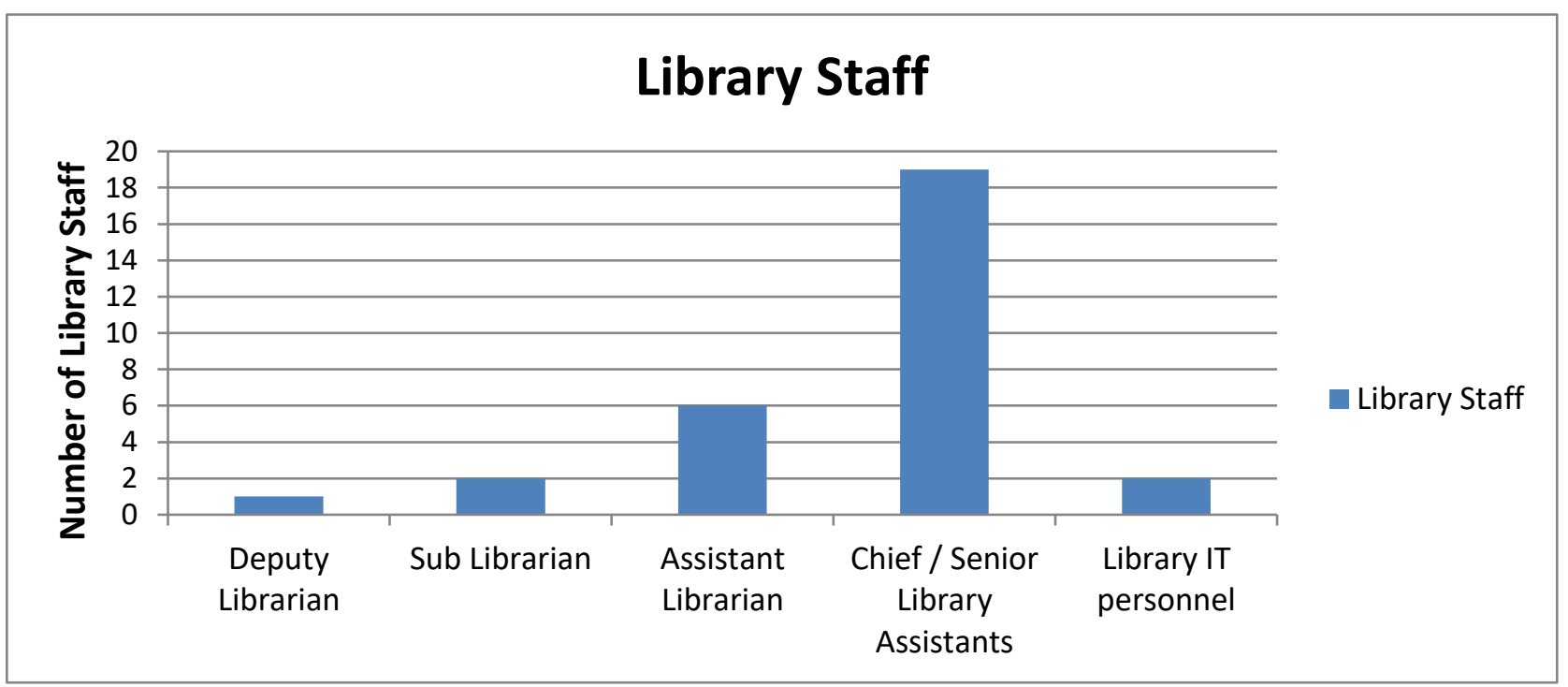

Figure 1: Distribution of Library staff by position

\subsection{Awareness of Digital Curation and Preservation}

Respondents were asked to indicate if they were familiar with the term digital curation or digital preservation. Ten (34\%) of Library Staff answered Yes and 19 (66\%) No. Interview results with the Deputy Librarian revealed that she was aware of the term digital preservation and not digital curation. The Library IT manager also explained that the term digital curation is new to him. He however explained that he was aware of digital preservation "in the sense of using open file formats". However, results from the focus group discussion revealed that few were aware of the term digital curation or digital preservation. One respondent said: "We were never taught that in library school".

\subsubsection{Level of Awareness of Digital Curation and Preservation}

The researcher needed a way of ascertaining the level of awareness of the library staff concerning digital curation and preservation. Therefore, questions that sought to measure the extent of awareness were included in the questionnaire. These included familiarities with different types of metadata and awareness of digital preservation strategies. 


\subsubsection{Familiarity with Metadata}

It was interesting to note that every staff member was aware of what metadata is. However, very few were familiar with the different metadata types. The exception was descriptive metadata where $86 \%$ of respondents were aware and $14 \%$ were not. Interview results with the library IT manager showed that he was aware of descriptive, technical and administrative metadata and not structural and preservation metadata.

As indicated in Table 2, most library staff were not completely familiar with most digital preservation strategies that may be applied in libraries. Ninety percent were not familiar with emulation and encapsulation; $93 \%$ were not aware of technology preservation; $69 \%$ were not aware of migration. Notably, however, only $31 \%$ were not aware of refreshing and $21 \%$ of metadata management.

Table 2: Awareness of Digital Preservation Strategies

\begin{tabular}{|l|l|l|l|}
\hline Strategy N=29 & $\begin{array}{l}\text { Familiar and } \\
\text { have used it }\end{array}$ & $\begin{array}{l}\text { Familiar and have } \\
\text { not used it }\end{array}$ & Not Familiar \\
\hline Refreshing & $17 \%$ & $52 \%$ & $31 \%$ \\
\hline $\begin{array}{l}\text { Technology } \\
\text { preservation }\end{array}$ & & $7 \%$ & $93 \%$ \\
\hline Migration & $7 \%$ & $24 \%$ & $69 \%$ \\
\hline Emulation & & $10 \%$ & $90 \%$ \\
\hline Encapsulation & & $10 \%$ & $90 \%$ \\
\hline $\begin{array}{l}\text { Metadata } \\
\text { Management }\end{array}$ & $69 \%$ & $10 \%$ & $21 \%$ \\
\hline
\end{tabular}

\subsection{Digital Curation and Preservation Competencies of Library Staff}

This study asked respondents to rate how they perceived their confidence in executing digital curation and preservation activities. The competencies and skills which were assessed were categorised into 4 categories namely;
i. Communication and interpersonal competency
ii. Curating and preserving content competency
iii. Curation technologies competency and
iv. Environmental scanning competency.

\subsubsection{Communication and interpersonal competency}

Communication and interpersonal competencies measures included presentation skills, clear articulation of solutions to information technology problems, communication and advocacy, as well as writing skills in the context of writing persuasive grant proposals. It was interesting to note that the majority of library staff indicated that they had above 'average' to 'excellent' skills in all these areas. However, on the negative side, a significant number of respondents (62\%) indicated that they were 'poor' in clear articulation of information technology problems. Figure 3 captures the findings of library staff communication and interpersonal competencies. 


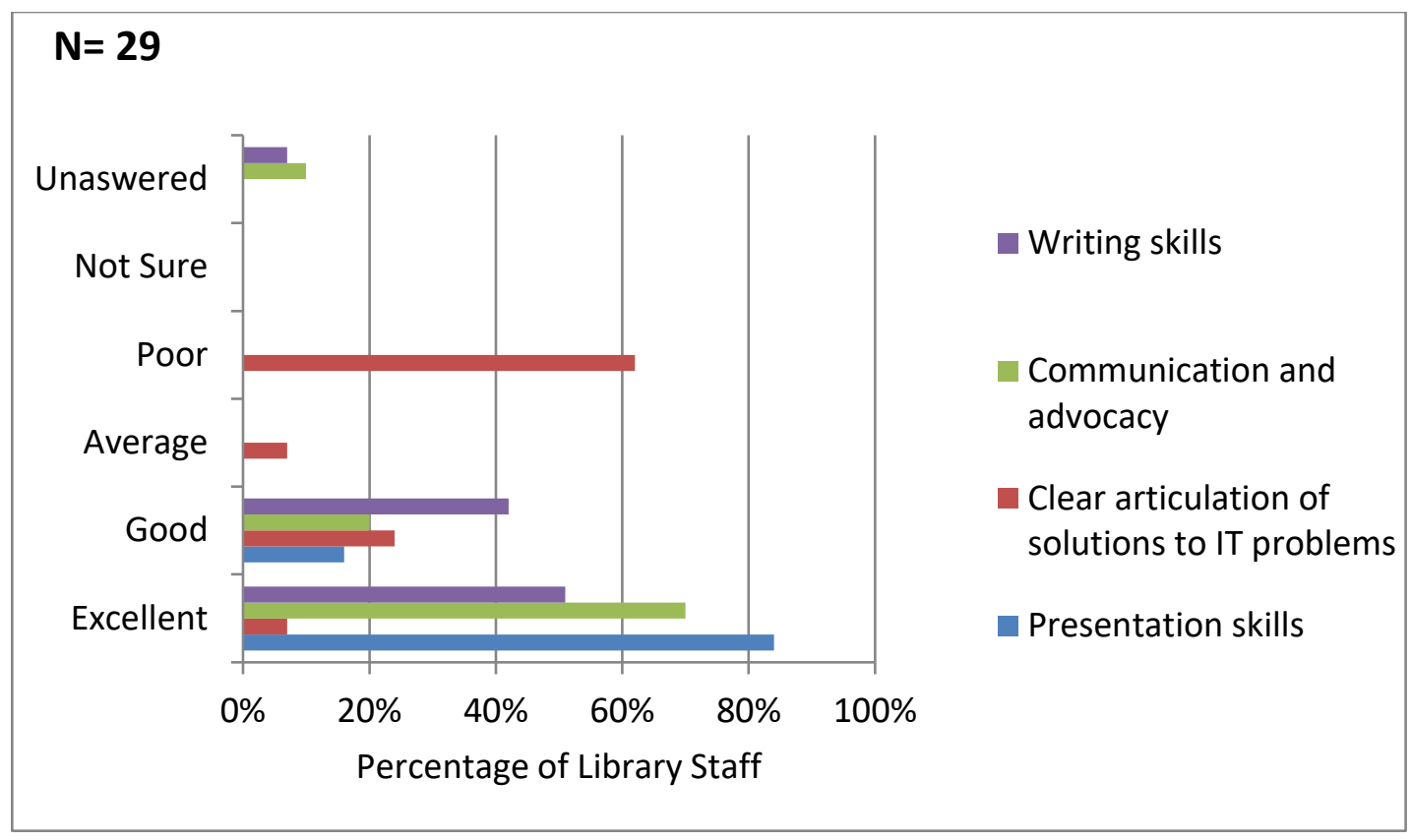

Figure 3: Communication and Interpersonal Competency

\subsubsection{Curating and Preserving Content Competency}

This category was operationalised into the following skills and competencies; electronic resources management, ability to use controlled vocabularies, ability to assign metadata to digital information, ability to use authority records, ability to use classification schemes and ability to identify file formats (Figure 4).

$\mathbf{N}=29$

Ability to identify file formats

Ability to use classification schema such as LCC, DDC, NLMC

Ability to use Authority records including AACR2 and RDA Ability to assign preservation metadata to digital information Ability to use controlled vocabularies Electronic resource management

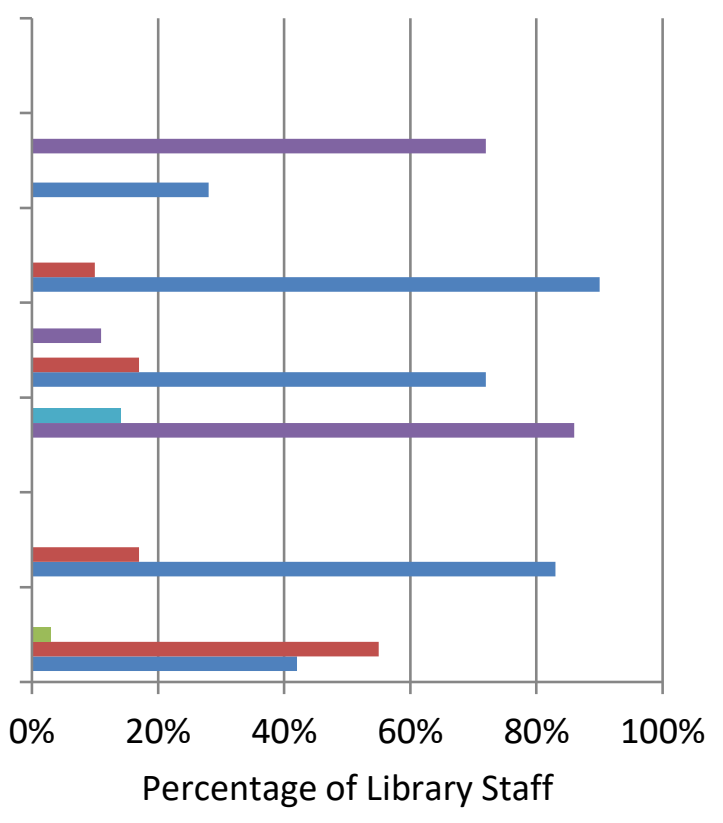

Not Sure

Poor

Average

Good

Excellent

Figure 4: Curating and Preserving Content Competency 
Results show that most library staff are good at using classification schemes (90\%), using controlled vocabularies (86\%), using authority records (72\%). However, most library staff rated themselves poor in assigning preservation metadata (86\%) and identifying file formats (72\%). Most of the competencies in this category were traditional library skills such as ability to use classification schemes and using authority records. These were rated mostly above average. However, technical skills identifying file formats and assigning preservation metadata to digital resources were rated as poor.

\subsubsection{Curation Technologies Competency}

Most skills in this category were rated as poor by most respondents (Figure 5). Eighty two percent said they were poor with database development and management, $69 \%$ with installing preservation systems, $61 \%$ with using digital curation workflow tools and $37 \%$ with using file conversion tools. On the positive side, $53 \%$ rated themselves as good in the use of scanners.

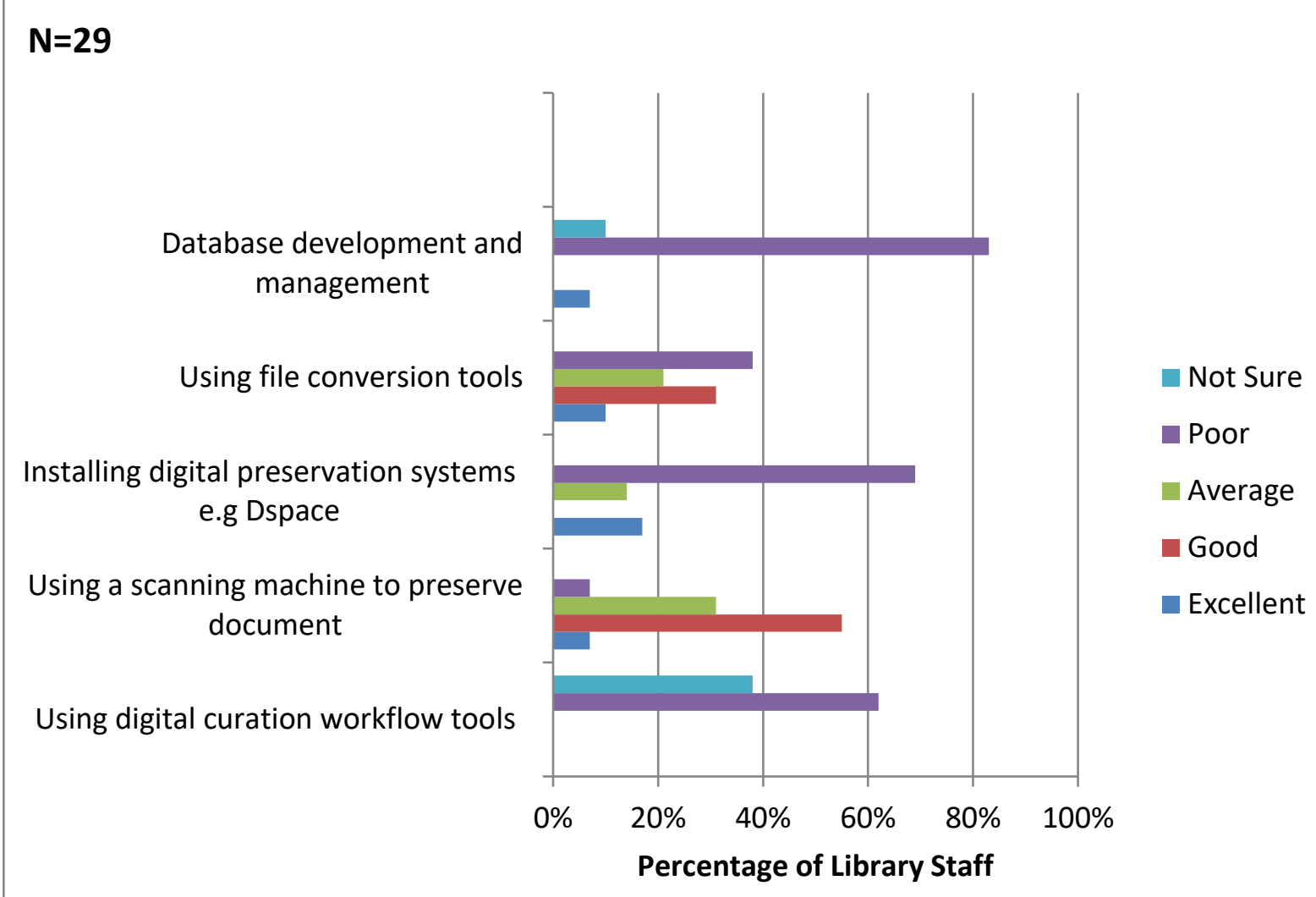

Figure 5: Curation Technologies Competency

\subsubsection{Environmental Scanning Competency}

This competency was about the ability of library staff to identify and use online resources to stay current and on the leading edge regarding trends, technologies and practices that affect professional work and capabilities within the field of digital curation. Most of the staff rated themselves above average (See Figure 6). 


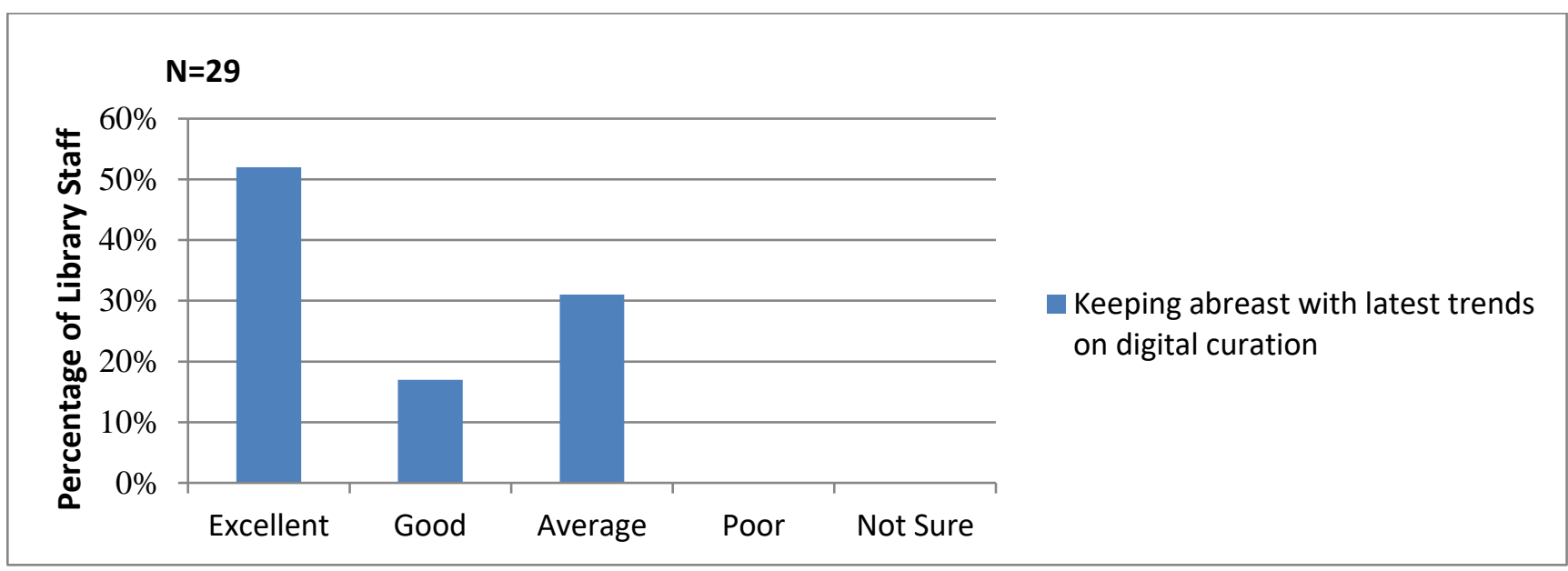

Figure 6: Environmental Scanning Competency

The library IT manager reported low level of skills to manage digital collections among library staff. He pointed out: "Library staff are way behind in terms of skills necessary to deal with digital collections". He lamented that most staff lacked the motivation to upgrade their skills. The focus group discussion revealed a low confidence among library staff in terms of digital curation and preservation skills. Most respondents stated that there was no emphasis on information technology skills in their library school training.

\subsection{Information Technology Infrastructure}

Library staff were asked to rate the extent to which they thought NUST Library had adequate technology infrastructure for digital curation and preservation. Figure 7 highlights the results. Two categories of infrastructure which were significantly rated as poor included, availability of desktop or work stations (63\%), digital curation workflow tools (62\%). The focus group discussion matched the ratings for availability of adequate computer workstations as they revealed that mostly Senior Library Assistants were using slow and outdated computers. The Deputy Librarian also indicated that the technology infrastructure available, has not been replaced for many years. However, $66 \%$ of library staff rated as 'excellent' the availability of information discovery systems. Interview results with the library IT manager confirmed the positive ratings for information discovery systems as the library was using a state of the art proprietary discovery system called Ebsco Discovery Tool. Most of the technology infrastructure categories were rated as 'not sure' and these include storage media (52\%), digital preservation management systems (55\%) and backup and disaster recovery tools (48\%). The focus group discussion confirmed these findings as most library staff revealed that they were not exposed to the library IT department and therefore were not familiar with some of the technology infrastructure.

The IT manager revealed inadequacy of technology infrastructures in terms of servers built purposely for digital collection. He said: "We have converted desktop computers to serve as servers for the library website, NuStone digital library and online research guides database and plans are underway to purchase a midrange server". The IT manager also indicated that there was need to revamp the library's IT infrastructure in general. 


\begin{tabular}{|c|c|c|c|c|c|c|c|}
\hline \multicolumn{8}{|c|}{$N=29$} \\
\hline \multirow{6}{*}{ 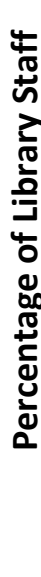 } & $\begin{array}{l}70 \% \\
60 \%\end{array}$ & & & & & & \\
\hline & $50 \%$ & & & & & & \\
\hline & $40 \%$ & & & & & & \\
\hline & $\begin{array}{l}30 \% \\
20 \%\end{array}$ & & & & & & \\
\hline & $10 \%$ & & & & & & \\
\hline & & $\begin{array}{l}\text { Adequate } \\
\text { Desktop/wor } \\
\text { k stations }\end{array}$ & $\begin{array}{c}\text { Storage } \\
\text { media }\end{array}$ & $\begin{array}{l}\text { Backup and } \\
\text { disaster } \\
\text { recovery } \\
\text { tools }\end{array}$ & $\begin{array}{c}\text { Digital } \\
\text { preservation } \\
\text { management } \\
\text { systems }\end{array}$ & $\begin{array}{c}\text { Digital } \\
\text { curation } \\
\text { software } \\
\text { workflow } \\
\text { tools }\end{array}$ & $\begin{array}{c}\text { Information } \\
\text { discovery } \\
\text { Systems }\end{array}$ \\
\hline \multicolumn{2}{|c|}{ Excellent } & $3 \%$ & $0 \%$ & $0 \%$ & & & $66 \%$ \\
\hline \multicolumn{2}{|c|}{ Good } & $17 \%$ & $14 \%$ & $0 \%$ & $17 \%$ & $0 \%$ & $17 \%$ \\
\hline \multicolumn{2}{|c|}{ Average } & $17 \%$ & $17 \%$ & $17 \%$ & $3 \%$ & $3 \%$ & $0 \%$ \\
\hline \multicolumn{2}{|c|}{ Poor } & $63 \%$ & $17 \%$ & $35 \%$ & $25 \%$ & $62 \%$ & $14 \%$ \\
\hline \multicolumn{2}{|c|}{ Not Sure } & $0 \%$ & $52 \%$ & $48 \%$ & $55 \%$ & $35 \%$ & $3 \%$ \\
\hline
\end{tabular}

Figure 7: Adequacy of Information Technology Infrastructure

\subsection{Digital Disaster Preparedness}

Preparedness for digital curation and preservation is also reflected in digital disaster preparedness. The library staff were asked their opinions on the likelihood of a number of digital disasters occurring at NUST Library as a way of ascertaining their level of awareness of the reality of digital disasters. Table 3 summarises the results. 
Table 3: Likelihood of Digital Disasters

\begin{tabular}{|l|l|l|l|l|}
\hline Digital Disaster & $\begin{array}{l}\text { Highly } \\
\text { Likely }\end{array}$ & Likely & Unlikely & $\begin{array}{l}\text { Not } \\
\text { Sure }\end{array}$ \\
\hline Fluctuation in power supply & $42 \%$ & $59 \%$ & $0 \%$ & $0 \%$ \\
\hline Power outage & $7 \%$ & $90 \%$ & $3 \%$ & $0 \%$ \\
\hline Software or hardware malfunctions & $76 \%$ & $24 \%$ & $0 \%$ & $0 \%$ \\
\hline Computer viruses & $69 \%$ & $28 \%$ & $3 \%$ & $0 \%$ \\
\hline Hacking of data & $66 \%$ & $31 \%$ & $3 \%$ & $0 \%$ \\
\hline Human errors like spilling of liquids & $24 \%$ & $7 \%$ & $69 \%$ & $0 \%$ \\
\hline Improper computer shutdown & $69 \%$ & $17 \%$ & $14 \%$ & $0 \%$ \\
\hline Accidental deletion of data & $48 \%$ & $45 \%$ & $0 \%$ & $7 \%$ \\
\hline Lightning/Heavy rain & $31 \%$ & $14 \%$ & $55 \%$ & $0 \%$ \\
\hline Fire & $17 \%$ & $21 \%$ & $62 \%$ & $0 \%$ \\
\hline $\begin{array}{l}\text { Collapse of whole or part of the } \\
\text { building }\end{array}$ & $79 \%$ & $17 \%$ & $3 \%$ & $0 \%$ \\
\hline
\end{tabular}

Most digital disasters in the questionnaire were rated as 'highly likely' and the highest was collapse of whole or part of the building (79\%) followed by software and hardware malfunctions with $76 \%$. The IT manager was also asked about the likelihood of digital disasters occurring. He explained that some digital collections were not being properly backed up such as the Nustone Digital Collection and the NuSpace Digital Collection and were at risk in the event of a digital disaster. He explained that workstation staff machines were being used as backups to save data.

\subsubsection{Digital Disaster Strategies at NUST Library}

In order to find out the extent to which NUST Library was prepared for digital disasters, respondents were asked an open ended question as to what strategies the library was using to prevent digital disasters. Seven (24\%) of the respondents highlighted that they were not aware of any strategy. Eight questionnaires were not answered on this particular question. Fourteen $(48 \%)$ of the library staff who responded to the question highlighted the following strategies:

\footnotetext{
i. Use of security guards

ii. Use of surge protectors

iii. Use of uninterruptible power supply (UPS)

iv. Daily tape backup of digital collections

v. Use of fire suppression equipment and extinguishers

vi. Use of antivirus software

vii. Use of passwords
}

Observation results concurred with the above findings and also reviewed the use of fire detection system, closed circuit television (CCTV), fire extinguishers and air conditioning of the server room. 
Interview results with the library IT manager revealed that not all IT equipment was covered with the uninterruptible power supply mechanism. The IT manager also indicated that backups of digital content were not regularly tested for readability and were not stored at a remote location in event of a digital disaster.

\subsubsection{Procedural and Technical Measures}

Focus group discussion confirmed the above findings and some staff members indicated that the library is covered under the university wide insurance in case of disasters. Some respondents said the following concerning insurance: "There is insurance cover whereby if we lost equipment we will get money to buy the equipment". "I understand the library equipment is insured $100 \%$... if we lost everything we get it back".

Interview results with the Deputy Librarian and the IT manager also concurred with the above observations. However, when asked whether the library is fully prepared for digital preservation, the Deputy Librarian pointed out that lack of funding was hindering the library from purchasing state of the art digital disaster mechanisms. She also lamented: "Fire canisters have not been serviced for the past two years". She also highlighted: "The library does not have any policies to deal with digital disasters or any disaster for that matter". Focus group discussions revealed that library staff had been trained only on using fire canisters twice in the last 5 years.

The library IT manager highlighted some unique issues that were not mentioned by other participants. He pointed out that the library is using open standards for file formats and data encoding in its digital collections as a way of reducing risk to inaccessibility of digital materials. He also pointed out the use of firewalls to protect library's digital collections and prevent unauthorised outsiders from accessing information. To this effect, the IT manager stated:

"The other measure we implemented to protect our systems and data from outside access, is putting in place a perimeter firewall which is CISCO 5520 certified".

The IT manager also highlighted the use of rights and privileges to ensure protection of digital collections. Rights and privileges were used to control access to unauthorized data. This was normally done depending on the functions or duties of each different person using the data or databases and applications in the network. The IT manager also highlighted the web access management system used to authenticate users who mainly want to access electronic journals and books off campus.

\subsection{Challenges to Digital Curation and Preservation}

Respondents were asked to indicate the challenges that they thought were making it hard for the library be fully engaged in digital curation and preservation activities. Library staff members indicated most of the challenges indicated in the questionnaire were critical, with all respondents (100\%) citing lack of funding and policy as major problem (See Table 4). Lack of technology infrastructure was rated a major challenge $(93 \%$, lack of skills $(86 \%)$ and resistance to change $(83 \%)$.

Table 4: Challenges of Digital Curation and Preservation

\begin{tabular}{|l|l|l|l|}
\hline Challenge N=29 & $\begin{array}{l}\text { Major } \\
\text { Challenge }\end{array}$ & $\begin{array}{l}\text { Minor } \\
\text { Challenge }\end{array}$ & $\begin{array}{l}\text { Not a } \\
\text { Challenge }\end{array}$ \\
\hline Lack of skills & $86 \%$ & $14 \%$ & \\
\hline $\begin{array}{l}\text { Technological } \\
\text { obsolescence }\end{array}$ & $69 \%$ & $21 \%$ & $10 \%$ \\
\hline
\end{tabular}

14/22 Ndhlovu, Phillip and Matingwina, Thomas (2018) The State of Preparedness for Digital Curation and Preservation: A Case Study of a Developing Country Academic Library, IASSIST Quarterly 42 (3), pp. 1-22. DOI: https://doi.org/ 10.29173/iq929 


\begin{tabular}{|l|l|l|l|}
\hline $\begin{array}{l}\text { Lack of technology } \\
\text { infrastructure }\end{array}$ & $93 \%$ & $7 \%$ & \\
\hline Lack of funding & $100 \%$ & & \\
\hline Lack of policy & $100 \%$ & & \\
\hline Resistance to change & $83 \%$ & $17 \%$ & \\
\hline Not in Library's mission & $17 \%$ & $52 \%$ & $31 \%$ \\
\hline Copyright clearance & $66 \%$ & $28 \%$ & $7 \%$ \\
\hline
\end{tabular}

Focus group discussions confirmed findings of the questionnaire as lack of funding, policy and skills were highlighted by most respondents. The Deputy Librarian and the library IT manager also echoed the same sentiments. The library IT manager also highlighted that there is low appreciation of the value of preserving digital information among the library key decision makers.

\section{Discussion of findings}

\subsection{Awareness of Digital Curation and Preservation}

The results of this study showed that only $32 \%$ of the library staff members were aware of the term digital curation or digital preservation and the majority; $68 \%$ were not aware. The low level of awareness among library staff members is consistent with (Ball, 2010) who highlights that the term 'digital curation' is relatively new, having been coined in 2001 as the title for a seminar on digital archives, libraries and e-Science.

The researcher probed the level of awareness further by asking library staff about their familiarity with different metadata types and awareness of digital preservation strategies. Results showed that $83 \%$ were not aware of structural metadata, $76 \%$ with administrative metadata, $93 \%$ with preservation metadata and $79 \%$ with technical metadata. However, most library staff $(86 \%)$ were aware of descriptive metadata. This might be because the digital collections the librarians dealt with require them to assign metadata. Results are consistent with those of Mutwiri (2014) who found high levels of awareness among library staff of descriptive metadata (86\%) and high levels of unawareness of other metadata types; $71 \%$ structural metadata, $69 \%$ administrative metadata, $73 \%$ preservation metadata and $78 \%$ technical metadata.

The study also revealed high levels of unawareness of digital preservation strategies; $90 \%$ were not familiar with emulation and encapsulation; $93 \%$ were not aware of technology preservation; $69 \%$ were not aware of migration. Results are consistent with those of Igberaese, Sambo and Saliu (2014) who found out low levels of awareness of digital preservation strategies by librarians in various libraries and institutions across Nigeria. In this study, $14 \%$ of the participants had acquaintance with migration; $16 \%$ with emulation and $14 \%$ with technology preservation. The results were also consistent with those of Mutwiri (2014) who found out low levels of awareness of between $18.8 \%$ and $43 \%$ in an investigation of library staff awareness of preservation strategies for digital materials. Similarly, Groenewald and Breytenbach (2011) found low levels of awareness in South African Libraries. However, this study also discovered that some librarians might be familiar with some of the digital preservation strategies but might have not been given the opportunity to use them in practice.

\subsection{Digital Curation and Preservation Competencies}

Excellent interpersonal, oral, written and online communication skills are highly desirable for personnel who work in the digital curation and preservation field (Engelhardt, Strathmann and 
McCadden, 2012). It was interesting to note that the majority of the library staff members indicated that they had above 'average' to 'excellent' skills in the communication and interpersonal competency. This seems to suggest that communication and interpersonal competencies are generic skills which can be easily applied in the digital curation and preservation field. However, on the negative side, a significant number of respondents $(62 \%)$ indicated that they were 'poor' in the clear articulation of information technology problems. This could be due to the fact that librarians are not exposed to the library IT department as interview results with the deputy librarian showed.

Results of the curating and preserving content competency ratings showed that most library staff were good at using classification schemes $(90 \%)$, using controlled vocabularies $(86 \%)$ and using authority records (72\%). These are traditional library skills and this might explain why library staff rated themselves highly. This also agrees with Bahr, Lindlar and Vlaeminck (2011) who note that digital curation and preservation utilizes traditional library skills. However, most library staff rated themselves poor in assigning preservation metadata (86\%) and identifying file formats $(72 \%)$. The results were also similar to those obtained for curation technology competencies were rated poorly. Eighty two percent said they were poor with database development and management, $69 \%$ with installing preservation systems, and $61 \%$ with using digital curation workflow tools. These skills are more on the technical side and might be explained by focus group discussion which reveals that the Library School curriculum covers less practical information technology skills.

\subsection{Information Technology Infrastructure}

Two categories of infrastructure which were rated as poor, availability of desktop or work stations (63\%), digital curation workflow tools (62\%). This could be explained by focus group discussions which indicated that mostly Senior Library Assistants have not received any new machines for the past 15 years. They relied mostly on donated machines. This is consistent with the results obtained by Zaveri (2015) who highlighted that libraries had not developed adequate IT infrastructure to support digital resources in India.

Most of the technology infrastructure categories were rated as 'not sure' and include storage media (52\%), digital preservation management systems (55\%) and backup and disaster recovery tools (48\%). Focus group discussions revealed that these technologies are in the custody of the library IT department which explains their limited knowledge. However, The Library IT manager also confirmed that these technology infrastructures are inadequate. According to (ICPSR, 2009) technological infrastructure which are needed for digital curation and preservation include the requisite equipment, software, hardware, which include operating systems, computers and storage media. However, it is apparent that NUST library lacks adequate infrastructure to support digital curation and preservation activities.

\subsection{Digital Disaster Preparedness}

The study sought to find out what the respondents thought about the level of preparedness for digital disasters. The study examined the likelihood of digital disasters at NUST Library, confidence in handling digital disasters and digital disaster prevention strategies being employed at the Library. Results showed that most digital disasters in the questionnaire were rated as 'highly likely' and 'likely' and the highest was the collapse of whole or part of the building (79\%) followed by software and hardware malfunctions with $76 \%$. This is in contrast to the findings of Zaveri (2015) in an investigation of digital disasters in India where the results of the study indicated that just over $50 \%$ of the librarians perceived less than $20 \%$ chance of digital disasters, while only $7.61 \%$ perceived a probability of over $60 \%$. The results of Zaveri were, however, due to the fact that the proportion of digital resources were relatively low compared to print resources. Observation results revealed a heavy reliance on digital resources at NUST library while digital disaster preparedness was lacking. This might explain why respondents rated digital disasters as highly likely and likely. 
The strategies that NUST library was using to prevent digital disasters as indicated by the study results included use of security guards, use of surge protectors, use of interrupted power supply (UPS), daily tape backup of digital collections, use of fire suppression equipment and use of antivirus software. This is in line with study findings by Njoroge (2014) in an investigation of disaster preparedness and mitigation for computer based information systems in selected university libraries in Kenya. Results revealed a number of measures that libraries were using to prevent digital disasters. These included physical measures, procedural measures, technical measures and awareness of computer based information systems (CBIS) measures.

The IT manager also indicated that backups to digital content were not regularly tested for readability and were not stored at a remote location in the event of a digital disaster. This is inconsistent with the recommendations by Mutula and Wamukoya (2007) who state that procedures for making backups should ensure that backup information should be stored at a location remote to the main site and backup data should regularly be tested for readability.

\subsection{Challenges to Digital Curation and Preservation}

The results for challenges to digital curation and preservation showed that $100 \%$ of the library staff members regard lack of funding and lack of policy as major challenges. Other major challenges include lack of skills (86\%), lack of technology infrastructure (69\%) and resistance to change. The results are similar to those of Kenney and Buckley (2005) in a survey carried out by the Cornell University Library in the United States. The results indicated that the main menace to digital materials were lack of policies and plans inside their institutions to carry out digital curation and preservation. The study results are also in line with DuraSpace (2013) which found out that $73 \%$ of selected academic libraries in the United States cited lack of funding. However, DuraSpace (2013) in the same study found out that only $23 \%$ cited lack of technical expertise and $23 \%$ cited lack of administrative support as barriers to digital curation and preservation. This is inconsistent with the study findings which cited lack of skills or technical expertise as a major challenge totaling $86 \%$ of the respondents.

The Library IT manager highlighted lack of appreciation by key decision makers on the value of digital preservation at NUST Library. This is in agreement with Voutssas, $(2012)$ who highlights cultural factors which include a lack of awareness among planners and decision makers about the value of digital curation and preservation as challenges facing libraries.

\section{Conclusions and Recommendations}

Despite the fact that NUST library has amassed a huge body of digital collections, there are no formal mechanisms in place to ensure accessibility and long-term preservation of digital content. The study sought to assess the preparedness of NUST library for digital curation and preservation of its digital collections. The findings of the study revealed a low level awareness of digital curation and preservation. Findings also indicated that the library lacks sufficient competencies or skills required for digital curation and preservation. However, the study established that librarians possess mostly traditional library skills which are also relevant in the field of digital curation and preservation. The study findings also showed that the library has inadequate infrastructure for digital curation and preservation and is lagging behind in comparisons libraries in the developed world. The preparedness of the library to handle digital disasters was of concern since no digital disaster plans were in place. The study revealed that most library staff members were not confident in handling digital disasters. However, the library has some mechanisms to prevent digital disasters, although these are not enough. Challenges to digital curation were mainly the lack of policies, lack of expertise and lack of funding. The library is not in a position to introduce research data management services with the current state of affairs. The challenges presented in this study will have to be addressed first. 


\subsection{Relevance of Conceptual Framework}

The conceptual framework was based on previous studies which assessed preparedness for digital curation and preservation of libraries and organisations in the field of information sector. The preceding discussion shows that the conceptual framework captured all the enabling and disabling factors for digital curation and preservation in libraries.

\subsection{Recommendations}

The following recommendations are made based on the findings of the study:

i. The library should consider digital curation and preservation as one of the primary responsibilities in order to ensure current and future access to digital collections by coming up with policies for managing digital content.

ii. Digital curation and preservation is highly essential especially for libraries which deal with digital collections. The library should consider sending staff members for specialised training to institutions with established mechanisms for digital preservation to help them to be conversant with digital curation workflows and digital preservation tools.

iii. The University should sponsor librarians to attend local and international workshops, conferences, trainings and seminars specific to digital curation and preservation in order to acquire the required skills.

iv. The library should consider lobbying all library schools in Zimbabwe to overhaul their curriculums in order to factor in digital curation and preservation as part of training required for information professionals.

v. The library should consider exposing library staff members to the library IT department as part of their duties in order to improve their information technology skills.

vi. The Library should come up with a disaster policy which incorporates digital disaster recovery plans.

vii. The library should ensure training and awareness of current digital disasters strategies such as a fire detection system and use of fire canisters.

viii. The library should conduct regular testing of backups to digital content as a way of ensuring that if anything happened to data or databases, then the backups could be used to restore the malfunctioning system.

\section{Recommendations for Further Research}

The results of this study cannot be easily generalised to other university academic libraries in Zimbabwe which are also on an accelerated drive to establish digital collections. Research is also needed to assess how well they are prepared for digital curation and preservation.

This study took a more generic approach in assessing the preparedness of NUST library for digital curation and preservation. There is a need for studies to assess specific technology systems being used by NUST library for digital preservation in order to provide additional insights on their capabilities to meet digital preservation requirements. 


\section{References}

Atkins, W. et al. 2013. Results of a Survey of Organizations Preserving Digital Content. [Online] Available from: http://www.digitalpreservation.gov/documents/NDSA-Staffing-Survey-ReportFinal122013.pdf [Accessed 2017 June 6]

Ball, A. 2010. Review of the State of the Art of the Digital Curation of Research Data. [Online] Available from: http://opus.bath.ac.uk/19022/2/ [Accessed 2017 June 6]

Bähr, T., Lindlar, M. and Vlaeminck, S. 2011. Puzzling over digital preservation - Identifying traditional and new skills needed for digital preservation. [Online] Available from: http://www.ifla.org/past-wlic/2011/217-bahr-en.pdf [Accessed 2017 June 8]

Boamah, E. 2014. Towards effective management and preservation of digital cultural heritage resources: an exploration of contextual factors in Ghana. [Online] Available from:

http://researcharchive.vuw.ac.nz/xmlui/bitstream/handle/10063/3270/thesis.pdf?sequence=2 [Accessed 2017 June 10]

Boyle, F., Eveleigh, A. and Needham, H. 2008. Report on the Survey Regarding Digital Preservation in Local Authority Archive Services. [Online] Available from:

http://www.dpconline.org/index.php?option=com docman\&task=doc download\&gid=338

[Accessed 2016 June 22]

Denscombe, M. 2008. Communities of practice: a research paradigm for the Mixed Methods approach. Journal of Mixed Methods Research (2)3: 270-283. [Online] Available from:

http://citeseerx.ist.psu.edu/viewdoc/download?doi=10.1.1.473.9571\&rep=rep1\&type=pdf

[Accessed 2017 Oct 28]

DuraSpace, 2013. Managing Digital Collections Survey Results Summary. [Online]

Available from:

http://www.duraspace.org/sites/duraspace.org/files/Managing\%20Digital\%20Collections\%20Survey \%20Results\%20Summary.pdf [Accessed 2018 Feb 26]

Engelhardt, C., Strathmann, S. and McCadden, K. 2012. Digital Curator Vocational Education Europe: Report on survey of sector training needs. [Online] Available from: http://www.adameurope.eu/pri/6880/pri/D3.1 TrainingNeedsSurvey.pdf [Accessed 2018 Jan 21]

Frank, R.D. and Yakel, E. 2013. Disaster Planning for Digital Repositories. [Online] Available from: https://www.asis.org/asist2013/proceedings/submissions/papers/59paper.pdf [Accessed 2017 July 16]

Groenewald, R. and Breytenbach, A. 2011. The use of metadata and preservation methods for continuous access to digital data. The Electronic Library, (29)2:236 - 248. [Online] Available from: http://dx.doi.org/10.1108/02640471111125195 [Accessed 2017 June22]

Hedstrom, M. 2001. Digital Preservation: Problems and Prospects. [Online] Available from: http://www.dl.slis.tsukuba.ac.jp/DLjournal/No 20/1-hedstrom/1-hedstrom.html [Accessed 2017 June 18]

Hockx-Yu, H. 2006. Digital preservation in the context of institutional repositories. Program Journal (40)3: 232 - 243. [Online] Available from: 
http://www.emeraldinsight.com/doi/full/10.1108/00330330610681312 [Accessed 2017 Aug 30]

ICPSR, Interuniversity Consortium for Political and Social Research. 2009. Principles and Good Practice for Preserving Data. [Online] Available from:

http://www.ihsn.org/home/sites/default/files/resources/IHSN-WP003.pdf [Accessed 2017 Aug 25]

International Records Management Trust, 2004. International Records Management Trust. [Online] Available from: http://www.irmt.org/ [Accessed 2018 Jan 5]

Jiazhen, L. and Daoling, Y. 2007. Status of the preservation of digital resources in China: results of a survey. Program Journal, (41)1:35 - 46. [Online] Available from:

http://www.emeraldinsight.com/doi/full/10.1108/00330330710724872 [Accessed 2018 Feb 6]

Johnson, R.B. and Onwuegbuzie, A.J. 2004. A Research Paradigm Whose Time Has Come. Educational Researcher, (33)7: 14-26. [Online] Available from:

http://edr.sagepub.com/content/33/7/14.full.pdf+html [Accessed 2018 Mar 5]

Kim, J., Warga, E. and Moen, W. 2012. Digital Curation in the Academic Library Job Market. [Online] Available from:

https://www.asis.org/asist2012/proceedings/Submissions/283.pdf [Accessed 2017 Aug 20]

Kitchenham, A.D.2010. Mixed Methods in Case Study Research. [Online] Available from:

https://srmo.sagepub.com/view/encyc-of-case-study-research/n208.xml [Accessed 2017 Oct 30].

Lee, C.A., Tibbo, H.R. and Schaefer, J. 2007. Defining what digital curators do and what they need to know: The DigCCurr project. Paper presented at the 7th ACM/IEEE-CS Joint Conference on Digital Libraries (JCDL), Vancouver, British Columbia, Canada.

Miles, M.B. and Huberman, A.M. 1994. Qualitative Data Analysis. Thousand Oaks, Calif. Sage.

Mutula, S. and Wamukoya, J. 2007. Web Information Management: A Cross-Disciplinary Textbook.

Oxford: Chandos Publishing

Mutwiri, C.M. 2014. Challenges Facing Academic Staff in Adopting Open Access Outlets for

Disseminating Research Findings in Selected University Libraries in Kenya. [Online] Available from:

http://ir-library.ku.ac.ke/bitstream/handle/ [Accessed 2017 July 2]

National Research Foundation. 2010. Managing Digital Collections: A Collaborative Initiative on the South African Framework. Pretoria: National Research Foundation.

Njoroge, R.W. 2014. An Investigation on Disaster Preparedness and Mitigation for Computer Based Information Systems in Selected University Libraries in Kenya. [Online] Available from: http://irlibrary.ku.ac.ke/bitstream/handle/ [Accessed 2017 July 4]

NUST, National University of Science and Technology Vice Chancellor's Annual Report, 2014. NUST Library 2014 Annual Report. Bulawayo: NUST Department of Communication and Marketing.

Pennock, M. 2006. Managing Digital Cultural Heritage Resources: From Digital Creation to Digital Curation. Information Scotland, (1):1-3. [Online] Available from: http://www.ukoln.ac.uk/ukoln/staff/m.pennock/publications/docs/info-scotland 200610.pdf [Accessed 2017 Aug 25] 
Raju, J. 2014. Knowledge and skills for the digital era academic library. The Journal of Academic Librarianship, (4002:163-170. [Online] Available from:

http://www.sciencedirect.com/science/article/pii/S009913331400024X [Accessed 2017 July 15].

Sinclair, P. et al. 2011. Are you Ready? Assessing Whether Organisations are Prepared for Digital Preservation. The International Journal of Digital Curation (6)1: 268-281. [Online] Available from: http://www.ijdc.net/index.php/ijdc/article/viewFile/178/247 [Accessed 2017 Sep 15]

Soehner, C., Steeves, C and Ward, J. 2010. E-Science and Data Support Services: A Study of ARL Member Institutions. [Online] Available from:

http://www.arl.org/storage/documents/publications/escience-report-2010.pdf [Accessed 2017 Sep 15]

Uluocha, A. 2014. Imperatives for Storage and Preservation of Legal Information Resources in a Digital Era. Information and Knowledge Management, (4)5:52-58. [Online] Available from: http://www.iiste.org/Journals/index.php/IKM/article/download/12905/13246 [Accessed 2017 Oct 1]

Voutssas, J. 2012. Long term digital information preservation: challenges in Latin America. Aslib Proceedings, (64)1:83 - 96. [Online] Available from: http://www.emeraldinsight.com/doi/full/10.1108/00012531211196729 [Accessed 2018 Feb 6]

Welman, C., Kruger, F., and Mitchell, B. 2005. Research methodology. Oxford : Oxford University Press.

Yin, R. K. 1984. Case study research: Design and methods. Newbury Park, CA: Sage.

Yale University Library, 2011. Best Practice Digital Resource Maintenance and Preservation Strategies. [Online] Available from:

http://www.library.yale.edu/iac/DPC/MaintenancePreservationStrategies09Apr2007.pdf [Accessed 2017 July 21]

Zaveri, P. 2015. Digital disaster management in libraries in India. Library Hi Tech (33)2: 230 - 244. [Online] Available from:

http://www.emeraldinsight.com/doi/full/10.1108/LHT-09-2014-0090 [Accessed 2017 July 9]

\section{End-notes}

1 Phillip Ndhlovu is the Institutional Repository Librarian at the National University of Science and Technology. He is also the liaison librarian for the Faculty of Commerce and can be reached by email: ndhlovup@gmail.com (version: July 2018)

${ }^{2}$ Thomas Matingwina is a lecturer in the Department of Library and Information Science at the National University of Science and Technology. (version: July 2018) 
